\title{
The relationship between level of education and moral judgment toward who abuse drugs
}

\author{
A relação entre nível de escolaridade e julgamento moral \\ para com quem abusa de drogas
}

Andrea Donatti Gallassi (https://orcid.org/0000-0003-1852-485X) ${ }^{1}$

Karina Diniz Oliveira (https://orcid.org/0000-0001-7388-0553) ${ }^{2}$

Maria de Nazareth Rodrigues Malcher de Oliveira Silva (https://orcid.org/0000-0003-4405-7378) ${ }^{3}$

Isabela Alves Machado (https://orcid.org/0000-0003-1968-5567) ${ }^{1}$

Gabriela Arantes Wagner (https://orcid.org/0000-0001-6070-7233) ${ }^{4}$

${ }^{1}$ Programa de PósGraduação em Ciências e Tecnologias em Saúde, Faculdade de Ceilândia, Universidade de Brasília.

Centro Metropolitano 1

Conjunto A, Ceilândia

Sul. 72220-900 Brasília DF

Brasil.andrea.gallassi@

gmail.com

${ }^{2}$ Departamento de Psiquiatria, Faculdade de

Medicina, Universidade Estadual de Campinas

(Unicamp). Campinas SP

Brasil.

${ }^{3}$ Curso de Terapia Ocupacional, Faculdade de Ceilândia, Universidade de Brasília. Brasília DF Brasil.

${ }^{4}$ Departamento de Medicina

Preventiva, Faculdade de

Medicina, Universidade

Federal de São Paulo. São

Paulo SP Brasil.

\begin{abstract}
The aim of the present study is to verify the differences of the moral judgment toward the people who abuse drugs according to the schooling of the participants. This is the Brazilian part of a multicentric study. $N=180$ individuals in a community in Brasilia, DF, Brazil; following consent, descriptive data were collected by anonymous interviewer-administered questionnaire that included socio-demographic, educational level and the history of drug use. Participants were predominantly females, middle-aged, married, employed, religious, with high school education; higher schooling considered alcohol abusers, marijuana, cocaine and crack are important as anyone else; the majority with lower education level knew someone who used drugs, but no association was found regarding drug use and schooling; in the unadjusted logistic regression model, positive associations were found between higher schooling and 'who use drugs are as important as anyone else' for all drugs studied; after adjusted, the association remained only for marijuana (all $p<0.05$ ). The negative attitude surrounding drugs issue can be an important obstacle. The results suggest that education can help to reduce the stigma associated; public policies would be important to minimizing social harm caused by stigmatized visions of drug users.
\end{abstract}

Key words Drug use, Schooling, Attitude, Stigma
Resumo Verificar as diferenças do julgamento moral em relação às pessoas que abusam de drogas de acordo com a escolaridade dos participantes. Parte brasileira de um estudo multicêntrico. $N=180$ indivíduos de uma comunidade em Brasília, DF, Brasil. Dados descritivos foram coletados por questionário que incluía dados sóciodemográfico, escolaridade e o histórico de uso de drogas. Os participantes eram predominantemente mulheres, de meia idade, casados, empregados, religiosos e com ensino médio; participantes com escolaridade superior consideraram abusadores de álcool, maconha, cocaina e crack importantes como qualquer outra pessoa; a maioria com menor nivel educacional conhecia alguém que usava drogas, mas nenhuma associação foi encontrada quanto ao uso de drogas e a escolaridade; no modelo de regressão logística não ajustada, associações positivas foram encontradas entre o ensino superior e "quem usa drogas são tão importantes quanto qualquer outra pessoa" para todas as drogas estudadas; Depois de ajustado, a associação permaneceu apenas para a maconha (para todos os dados $p<0,05)$. A escolaridade pode ajudar a reduzir o estigma associado aos usuários de drogas; políticas públicas podem minimizar os danos sociais causados por tais visões estigmatizadas.

Palavras-chave Uso de drogas, Escolaridade, Atitude, Estigma 


\section{Introduction}

The complexity surrounding the consumption of drugs is becoming increasingly evident, requiring broad understanding of the subject ${ }^{1}$. Knowledge, attitude and practice among the general public and health professionals can affect the quality of services that drug abusers receive, their adherence to treatment and also their quality of life in terms of their relationships ${ }^{2,3}$. Beyond the physical effects caused by the ingestion of drugs, such as organ damage, people who abuse drugs face social consequences resulting from social attitudes of others towards them ${ }^{4}$.

Researchers have reported that the effects of drugs are the result of complex interactions among pharmacological, psychological, and environmental factors, producing different responses in different individuals ${ }^{5}$. The effects of drug use affect the attitudes of those who interact with drug abusers, and their attitudes are further influenced by their knowledge, beliefs, culture and values.

Psychoactive substance use disorders go far beyond a physical problem. Besides the effects of substances on the behavior of the individual, there are social, political and economic factors that involve the user and contribute to their marginalization. Thus, social inequities, lack of housing, low access to health services and education, public policies of criminalization of substance use are factors that aggravate the use and increase the morbidity of the user ${ }^{6}$.

In addition, there is often a limitation on livelihoods, which may lead to illegal activities (such as selling drugs, stealing), or scorned, such as prostitution and begging. All these factors contribute both to the context of violence in which the user is involved and to the moral judgment of them either?

\section{Manifestations of attitudes: the moral judgments}

The definition of 'attitude' has shifted over the years, becoming more focused ${ }^{8}$. Early researchers in this field have defined attitude as $a$ mental and neutral state of readiness, organized through experience, exerting a directive or dynamic influence upon the individual's response to all objects and situations in which it is related ${ }^{9}$ (p.810). However, by 1948, scholars conceptualized attitude as an enduring organization of motivational, emotional, perceptual and cognitive processes with respect to some aspect of the individual's world ${ }^{10}(\mathrm{p}$. 152). In 1993, the concept was refined even further as a psychological tendency that is expressed by evaluating a particular entity with some degree of favor or disfavor ${ }^{11}$ (p.1).

The evaluative component of attitude is an important determinant of behavior ${ }^{8}$. Consequently, much of the research on attitude is based on the idea that one's memory organizes attitudes by using a positive or negative evaluative index ${ }^{12}$. Moral judgments - one of the components of attitude -about drug abuse may influence their access to treatment; among health professionals, perceptions of patient responsibility can affect willingness to offer help and judgments about the presenting condition ${ }^{13}$. Moral judgment related to people with mental illness and drug use can vary depending on socio-demographic characteristics, such as gender, culture, age, education and place of residency. Stigma is the most consistent theme emerging from a review of the literature on attitudes of people in the general population towards people with alcohol and other drug related problems. Perceived dangerousness and desire for social distance, identified as measures of stigma, emerged as secondary themes ${ }^{14}$. Most of the research was/has focused on attitudes toward alcohol and other drug addiction along with several other mental disorders and, in some cases, physical illnesses.

A review of the literature conducted by Pescosolido $^{14}$ examined the possibility that education about drug abuse and addictions would decrease stigma. He concluded that instead of decreasing stigma, understanding addiction as a disease increased stigma. He theorized that understanding addiction as a disease entity could produce a sense of permanence of the condition. They cautioned that education may not be sufficient to bring about or maintain change. Instead, a creative and sustained effort is most likely to produce desirable results. Schomeruset. al. ${ }^{15}$, also concluded that attitudes toward the people who abuse drugs are consistent over time.

The present article aims to verify the differences of the moral judgment toward the people who abuse drugs according to the schooling of the participants of the multicentric study Attitudes in ten urban communities toward persons who abuse drugs, in a Brasilia community, DF, Brazil. 
part of the multicentric study Attitudes in ten urban communities toward persons who abuse drugs, carried by ten countries in Latin America and the Caribbean (Bahamas, Belize, Chile, Ecuador, Guyana, Jamaica, Nicaragua, Peru and Trinidad and Tobago) supported by CICAD/OEA (Inter-American Drug Abuse Control Commission Organization of American States) and held in 2013 at the Center for Addiction and Mental Health (CAMH) affiliated with the University of Toronto, Canada.

\section{Subjects}

The selection of the convenience sample was performed in three stages: (a) selection of the target community, (b) selection of households and (c) selection of participants. The selection of the target community followed the criteria established by the team of the multicenter study, being: "urban" area next to the linker university of the lead researcher - in the Brazil case is the University of Brasilia in Brasilia, Federal District - with a population between 5 and 15 thousand inhabitants, of intermediate social class. The selection of households has considered the following criteria: houses with at least one adult, aged between 18 and 65 years in the target community, which could provide informed consent. People under 18 years of age or older than 65 years were excluded.

\section{The instrument}

Multidimensional Attitude Inventory (MAI): The MAI was developed by the group of the 10 researchers from the ten Latin American and $\mathrm{Ca}$ ribbean countries. The MAI was built on based from three internationally validated instruments that have been used to measure attitudes towards people who abuse alcohol or other drugs ${ }^{16-18}$, and also taking in consideration the different cultural aspects of the countries participants to measure the attitudes of the general population towards abusers of the following drugs: alcohol, marijuana, cocaine and crack in various dimensions, from positive to negative.

Three scales make up the MAI: (1) Personal Contact Scale specifically measures person's feelings and how they believe they would act if they have to come into contact with persons who abuse drugs in two distinct domains, being: (1) meso (relationship between microsystems) and (2) exosystem (external influences). This scale contains 5 items which 4 are in the mesosystem domain and 1 in the exosystem domain; these items access attitudes through 2 questions about feelings and 3 about behavioral intent towards persons who abuse drugs. The (2) Judgment Scale specifically measures person's thoughts about those who abuse drugs in three domains (mesosystem, exosystem and macrosystem); these domains correspond to internal attributions of actions within the persons control and external attributions of conditions outside of the person's control. The scale contains 5 items which 1 is in the mesosystem domain, 2 in the exosystem domain and 5 in the macrosystem domain, considering that some questions are in 2 domains. The five items assess attitudes through 5 questions about cognition towards persons who abuse drugs. The (3) Social Support Scale specifically measures person's thoughts and feelings about services for people who abuse drugs in the distinct domains. The social support scale contains 5 items which 1 is in the mesosystem domain, 2 are in the exosystem domain and 4 are in macrosystem domain, considering that some questions are in 2 domains. The five items assess attitudes through 1 question about feelings and 4 about cognition towards persons who abuse drugs.

After the conception of the final version of the instrument in English, it was translated into Portuguese - restricted only to aspects related to language - and tested in 3 stages (1) first performed by the group of researchers that make up the Center of Drugs And Associated Vulnerabilities (CRR/FCE/UnB), link: dgp.cnpq.br/dgp/ espelhogrupo/4817837547822266l, University of Brasilia, DF, Brazil; (2) The second was carried out with students of scientific initiation - who would be the implementers of the instrument of the next stage; And (3) the third was carried out with a sample of health professionals and social workers participating in the drug training processes proposed by CRR/FCE/UnB. 


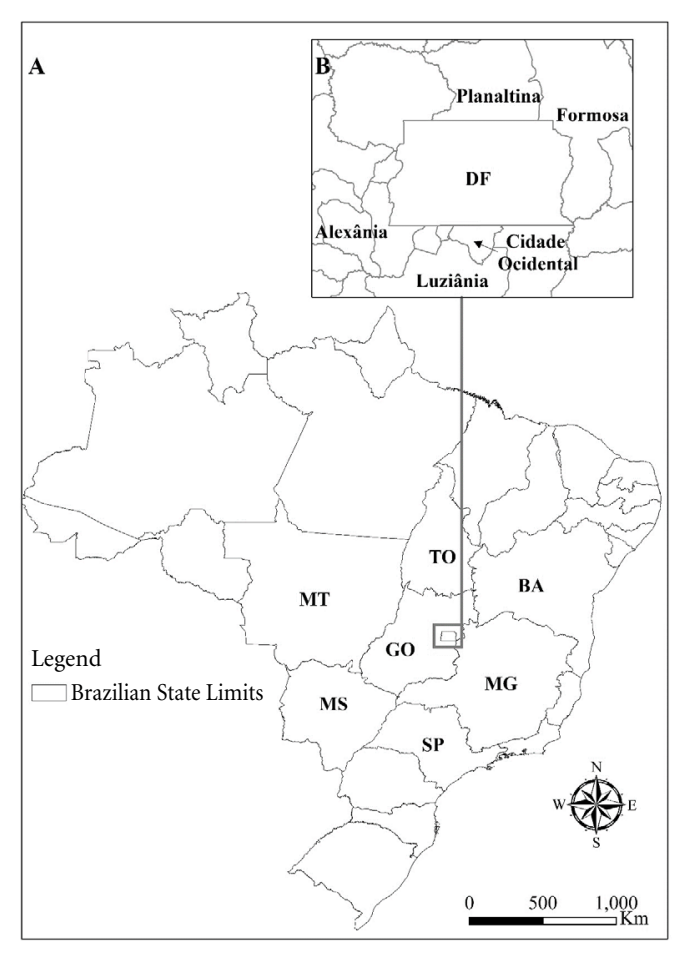

Figure 1. Location of Brasília, Federal District, in the Brazil map.

Source: Library maps Program R (https://rstudio-pubs-statics3 .amazonaws.com/176768_ec7fb4801e3a4772886d61e65885fbd d.html).

\section{Study variables}

\section{Dependent variable}

The dependent variable of the current study was the educational level. The participants were asked "What is the highest level of education you attended?" The responses to these variables were categorized as 'elementary school' and 'high school'.

\section{Independent variables}

The following variables collected during the interview were analyzed: sex (men/women), marital status (single or divorced/married), religiosity (no/yes); age (18-29/30-49/50-65); and employed (no/yes). The variable "Have you ever used drugs?” included a self-report of use at least one time of the following substances: alcohol, marijuana, cocaine and crack. As for personal experience with drug use, the variable "Do you know anyone who abuse?” (no / yes) was analyzed for each of the drugs investigated.
For the purposes of this study, one question about moral judgment of the Multidimensional Attitudes Inventory (MAI) was analyzed like an independent variable: "Do you think a person who abuses (alcohol/marijuana/cocaine/crack) is as important as anyone else?" For purposes of analysis, the responses to these variables were grouped as [(yes = definitely yes/probably yes); (I do not know = I'm not sure $)$; (No = probably not/definitely not)].

\section{Statistical analysis}

Descriptive analyses were conducted for the sociodemographic characteristics, moral judgment for each drug, history of drug use and person known to have abused some one of drugs by level of education. Inter-group comparisons were made using Pearson's chi-square $\left(\chi^{2}\right)$. All p-values $<0,050$ were considered statistically significant. Logistic regression model was used to verify the association between educational level and moral judgment. The reference category for this analysis was "elementary school" in comparison with "high school". Analyses were performed using the Stata ${ }^{\circledR}$ statistical software package, version 14. Associations with a p-value $<0,20$ in the univariate analyses were incorporated into the logistic regression using forward selection. The magnitude of the associations was estimated using odds ratios and their respective 95\% confidence intervals. The moral judgment on crack was not significant in the final model and was excluded because there was no variation greater than $10 \%$ in the other parameters estimated after their exclusion.

\section{Results}

Of the 180 participants, there was a greater proportion of females (58\%), aged 30-49 (40,2\%), followed by $18-29$ years $(33,7 \%)$ and $50-65$ years $(26,0 \%)$, declared to be religious $(78,1 \%)$, married $(61,6 \%)$, and employed $(62,2 \%)$ at the time of the survey. Most those participants had attended high school $(64,6 \%)$ and the others $(35,4 \%)$ to elementary school (data no shown).

About sociodemographic characteristics, significant differences were found only in age $(\mathrm{p}=0,001)$ and work $(\mathrm{p}<0,001)$. Regarding the moral judgment between the different levels of education, it was possible to verify that the participants with higher schooling considered alcohol abusers $(p=0,034)$, marijuana $(p=0,002)$, cocaine $(\mathrm{p}=0,035)$, are important as anyone else. 
But no differences was found regarding the use of crack for any level of schooling (Table 1).

The unadjusted and adjusted logistic regression models are presented in Table 2. There were positive associations between higher schooling and the fact of considering individuals who use drugs are as important as anyone else in the unadjusted models, and the largest association found was for marijuana, followed by cocaine, alcohol and crack. After adjusting the models (by age and employed), the association remained only for marijuana. Individuals with higher level of education had 4.26 times the chance to consider that the marijuana abuser is as important as anyone else.

\section{Discussion}

This study sought to present different elements that interfere in the way the population judges drug users, with emphasis on the participant's level of education.

Table 1. Distribution of sociodemographic, drug use and moral judgment characteristics by level of education of the community in Brasília, Federal District, Brazil, of the Attitude study, 2014 ( $\mathrm{N}=180)$.

\begin{tabular}{|c|c|c|c|c|}
\hline & & $\begin{array}{c}\text { Elementary } \\
\text { school }\end{array}$ & $\begin{array}{l}\text { High } \\
\text { school }\end{array}$ & $\begin{array}{c}\text { p- } \\
\text { value }^{1}\end{array}$ \\
\hline & & 37,6 & 62,4 & \\
\hline Marital status & Single/Divorced & 31,9 & 68,1 & 0,392 \\
\hline & Married & 38,2 & 61,8 & \\
\hline Sex & Men & 40,9 & 59,1 & 0,466 \\
\hline & Women & 35,4 & 64,4 & \\
\hline Religiosity & No & 36,8 & 63,2 & 0,852 \\
\hline & Yes & 35,2 & 64,8 & \\
\hline Age & $18-29$ & 18,6 & 81,4 & 0,001 \\
\hline & $30-49$ & 37,8 & 62,2 & \\
\hline & $50-65$ & 54,4 & 45,6 & \\
\hline Employed & No & 52,9 & 46,1 & $<0,001$ \\
\hline & Yes & 25,0 & 75,0 & \\
\hline A person who abuses alcohol is as important as anyone else $^{2}$ & No & 54,8 & 46,2 & 0,034 \\
\hline & I do not know & 33,3 & 66,7 & \\
\hline & Yes & 31,7 & 68,3 & \\
\hline A person who abuses marijuana is as important as anyone & No & 60,7 & 39,3 & 0,002 \\
\hline & I do not know & 55,6 & 44,4 & \\
\hline & Yes & 29,6 & 70,4 & \\
\hline A person who abuses cocaine is as important as anyone else & No & 58,3 & 41,7 & 0,035 \\
\hline & I do not know & 50,0 & 50,0 & \\
\hline & Yes & 31,9 & 68,1 & \\
\hline A person who abuses crack is as important as anyone else & No & 54,8 & 45,2 & 0,051 \\
\hline & I do not know & 33,3 & 66,7 & \\
\hline & Yes & 31,7 & 68,3 & \\
\hline Do you know anyone who abuse? & No & 28,2 & 72,0 & 0,393 \\
\hline & Yes & 36,9 & 63,1 & \\
\hline Have you ever used drugs? & No & 36,0 & 64,0 & 0,655 \\
\hline & Yes & 40,9 & 59,1 & \\
\hline
\end{tabular}

1. Chi-square test; 2 . For the purposes of this study, one question about moral judgment of the Multidimensional Attitudes Inventory (MAI) was analyzed like an independent variable: "Do you think a person who abuses [for each drug] is as important as anyone else?" For purposes of analysis, the responses to these variables were grouped as [ (Yes = definitely yes / probably yes); (I do not know = I'm not sure); (No = probably not / definitely not $)]$. 
Table 2. Associations of education level and moral judgment characteristics of the community in Brasília, Federal District, Brazil, of the Attitude study, $2014(\mathrm{~N}=180)$.

\begin{tabular}{|c|c|c|c|c|c|}
\hline & \multicolumn{5}{|c|}{ High school $^{1}$} \\
\hline & & UnOR(95\%CI) & p-value & $\operatorname{AdOR}(95 \% \mathrm{CI})^{3}$ & p-value \\
\hline \multirow{3}{*}{$\begin{array}{l}\text { A person who abuses alcohol is as } \\
\text { important as anyone else } e^{2}\end{array}$} & No & 1 & & 1 & \\
\hline & I do not know & $0,85(0,12-5,99)$ & 0,87 & $0,31(0,27-4,65)$ & 0,398 \\
\hline & Yes & $2,73(1,15-6,50)$ & 0,022 & $1,72(0,52-5,70)$ & 0,372 \\
\hline \multirow{3}{*}{$\begin{array}{l}\text { A person who abuses marijuana } \\
\text { is as important as anyone else }\end{array}$} & No & 1 & & 1 & \\
\hline & I do not know & $1,23(0,27-5,64)$ & 0,784 & $1,72(0,27-10,85)$ & 0,560 \\
\hline & Yes & $3,67(1,58-8,52)$ & 0,002 & $4,26(1,01-17,89)$ & 0,048 \\
\hline \multirow{3}{*}{$\begin{array}{l}\text { A person who abuses cocaine is as } \\
\text { important as anyone else }\end{array}$} & No & 1 & & 1 & \\
\hline & I do not know & $1,40(0,23-8,42)$ & 0,713 & $0,50(0,52-4,93)$ & 0,560 \\
\hline & Yes & $2,97(1,23-7,20)$ & 0,015 & $0,34(0,67-1,81)$ & 0,211 \\
\hline \multirow{3}{*}{$\begin{array}{l}\text { A person who abuses crack is as } \\
\text { important as anyone else }\end{array}$} & No & 1 & & & \\
\hline & I do not know & $2,42(0,38-15,27)$ & 0,344 & - & - \\
\hline & Yes & $2,61(1,18-5,77)$ & 0,014 & - & - \\
\hline
\end{tabular}

1. Logistic regression with elementary school as reference; 2. For the purposes of this study, one question about moral judgment of the Multidimensional Attitudes Inventory (MAI) was analyzed like an independent variable: "Do you think a person who abuses [for each drug] is as important as anyone else?" For purposes of analysis, the responses to these variables were grouped as [ $($ Yes $=$ definitely yes / probably yes); (I do not know = I'm not sure); (No = probably not / definitely not)]; 3. Model adjusted by age and employed.

Source: Attitude study, 2014.

In Brazil, schooling is a factor directly associated with the socioeconomic level, although education is, in theory, available to all, social inequities often make it difficult for individuals to progress in their studies. In this way, schooling becomes an important reference for measuring other parameters of the individual's social situation, including access to information.

The participants' years of schooling seemed to influence the moral judgment of drug users, regardless of their offensive potential. In our results, the most educated participants considered that the marijuana, crack, or cocaine abuser is "as important as anyone else"; Marijuana and crack users, however, were considered morally weak.

Level of education was also an important element in studies that evaluated stigma in relation to substance users. In a paper published in 2014, which evaluated 531 responses from randomly chosen people, found that education contributes significantly to reducing the stigma associated with the use of psychoactive substances ${ }^{19}$.

Drug-related stigma is a multifactorial phenomenon and our results suggest that educational level should not be considered in isolation as a predictor of behavior. The social context of the individual, his religiosity, the substance used and the harm caused by it are important elements that should be considered for further analysis.

Knowing people who use drugs was reported by participants who declared lower schooling, but in our results this was not shown to be an important factor influencing moral judgment in relation to the user. A 2012 study conducted in the USA found similar results ${ }^{20}$. But this is not unanimous in the literature: among students, a 2011 study concluded that there is association between less previous contact and higher stigma related rejection, especially with regards to heavier drugs. Students reported that they preferred to remain socially distant from drug users ${ }^{21}$. Another study done among adolescents also showed similar results, suggesting that drug use or close cohabitation with users causes the stigmatized perception of the user to decrease considerably. Stigma against individuals who are addicted to drugs is inversely related to adolescents' own drug use and the prevalence of drug use (specifically marijuana and hashish) among close friends ${ }^{22}$. Although causal direction cannot be determined from this study, the results suggest that familial or contact with drug is indeed related to a reduction in stigma. 
Despite high perceived public stigma levels attached to individuals with any substance use problem, these stigma perceptions may vary by drug type. Understanding the social context of use and the elements that involve the interviewed population is essential so that the answers can be adequately analyzed.

Marijuana is the illicit drug most commonly used in the world and in Brazil, between 6.8\% and $8.8 \%$ of the population, reported use in the life of this drug ${ }^{23,24,25}$.

The results of our study, which suggested less stigma about the marijuana user, can be explained by both the higher prevalence and the lower offensive potential of this drug compared to the other studied ${ }^{22,27}$. Previous research suggests that each drug is associated with its own level of stigma due to varying levels of social acceptability and potential for harm.

Brown ${ }^{28}$ considers that the level of social acceptance of each drug varies according to the environment and also with the degree of damage caused to the individual and society, which influences the social acceptance of the drug. This research showed that the heroin user population suffers more stigma than marijuana users; the fact that marijuana is not considered a less harmful potential drug, he concludes, should be considered in that result. In a study with 1021 people in the United States, who were asked about stigma in relation to various substances, it was marijuana abusers who suffered the least stigma in relation to cocaine and opioid users ${ }^{20}$.

This may be due to the fact that other illicit drugs are more associated with dangerousness, unemployment and association with other diseases, such as schizophrenia and AIDS, also stigmatizing ${ }^{29}$.

Religion should also be considered an important factor influencing people's moral judgment of users. In the present study, when asked about crack use, people who claimed to have a re- ligion considered the user "as important as anyone else", despite the great offensive potential of this drug. Studies show that religious groups tend to accept the drug user more without stigmatizing it, which often contributes to their recovery ${ }^{30}$.

There is evidence that moral values and optimism stemming from religiosity are protective factors for alcohol abuse and dependence; moral values and the value of forgiveness tend to increase the tolerance of people with greater religiosity, which may also justify the participants' responses ${ }^{31,32}$.

The results of these studies suggest that substance-related addictions are often viewed by the public as acts of personal choice and / or moral failure, and less likely to be considered medical conditions. Further, addiction-related stigma has an adverse effect on the mental health status because internalized shame and creates emotional distress.

\section{Conclusions}

The results of the present study suggest that the stigma suffered by drug users can be influenced by several factors: the substance used, the educational level of the participants and the fact that they are religious. Factors such as knowing someone who uses or has already been a user did not seem to influence the moral judgment of the people who responded to this research.

Drug abuse is a global public health problem. The negative attitude surrounding this issue can be an obstacle to the proper approach of users, contributing to the aggravation of the problem. Our results suggest that education and information regarding use can help to reduce the stigma associated with the person who makes drug abuse. In this way, public enlightenment policies would be important to increase success in preventing and minimizing social harm caused by stigmatized visions of drug users.

\section{Limitation}

This study has some limitation. During the data collect, some of the participants had been distracted by the children who were looking after and it could have impacted in the quality of their answers. None of the others countries which make part of the multicentric study have been published articles to be possible make comparison with the data presented in this manuscript. 


\section{Collaborators}

All authors have substantially contributed to the writing and editing of the manuscript, since de first draft until the final version, and all of them have approved the submission.

\section{Ethical considerations}

The present study received approval from the Human Research Ethics Committee of the Faculty of Health Sciences, University of Brasilia. All participants signed the document to consent and permit the information publishing provided by them for scientific reasons.

\section{Funding Information}

Resource support making the present study possible came from the CICAD/OAS - Inter-American Commission on Drug Abuse/Organization of American State, by the International Research Capacity Building Program for health related professionals to study the drug phenomenon in Latin America and the Caribbean - 2013/2014 (there is no grant numbers; it was a scholarship).

\section{References}

1. Ronzani T, Higgins-Biddle J, Furtado E. Stigmatization of alcohol and other drug users by primary care providers in Southeast Brazil. Soc Sci Med 2009; 69(7):1080-1084.

2. Berger $\mathrm{M}$, Wagner $\mathrm{T}$, Baker L. Internet use and stigmatized illness. Soc Sci Med 2005;61(8):1821-1827.

3. Gallassi A, Nakano E, Wagner G, de Oliveira Silva M, Fischer B. Characteristics of clients using a community-based drug treatment service ('CAPS-AD') in Brazil: An exploratory study. International J Drug Policy 2016; 31:99-103.

4. Room R. For alcohol alternatives, the science is not the hardest part. J Psychopharmacol 2005; 20(3):323324.

5. Crombag H, Robinson T. Drugs, Environment, Brain, and Behavior. Curr Dir Psychol Sci 2004; 13(3):107111.

6. Strathdee SA, Hallett TB, Bobrova N, Rhodes T, Booth R, Abdool R, Hankins CA. HIV and risk environment for injecting drug users: the past, present, and future. Lancet 2010 Jul 24; 376(9737):268-284.

7. Richardson LA, Long C, DeBeck K, Nguyen P, Milloy MJ, Wood E, Kerr TH. Socioeconomic marginalisation in the structural production of vulnerability to violence among people who use illicit drugs. J Epidemiol Community Health 2015 Jul; 69(7):686-692.

8. Wittenbrink B, Schwarz N. Implicit measures of attitudes. New York, NY: Guilford Press; 2007.

9. Murchison C, Allee W. A handbook of social psychology. New York: Russell \& Russell; 1967.

10. Krech D, Crutchfield R. Theory and problems of social psychology. New York: McGraw-Hill; 1948.

11. Haddock G. The psychology of attitudes. Los Angeles [U.A.]: Sage; 2012.

12. Irle M. The relationship of connected attitudes with knowledge about the attitude object. Acta Psychol 1961; 19:555-556.

13. Corrigan PW, Lurie BD, Goldman HH, Slopen N, Medasani K, Phelan S. How adolescents perceive the stigma of mental illness and alcohol abuse. Psych Serv 2005; 56(5):544-550.

14. Pescosolido B. The Public Stigma of Mental Illness. J Health Soc Behav 2013; 54(1):1-21.

15. Schomerus G, Lucht M, Holzinger A, Matschinger $\mathrm{H}$, Carta M, Angermeyer M. The Stigma of Alcohol Dependence Compared with Other Mental Disorders: A Review of Population Studies. Alcohol Alcohol 2010; 46(2):105-112.

16. Parrillo V, Donoghue C. Updating the Bogardus social distance studies: a new national survey. Soc Sc J 2005; 42(2):257-271.

17. Bryan A. Drug-related knowledge, attitudes and beliefs in Ireland. Dublin: Drug Misuse Research Division, Health Research Board; 2000.

18. Luke D, Ribisl K, Walton M, Davidson W. Assessing the diversity of personal beliefs about addiction: development of the Addiction Belief Inventory. Subst Use Misuse 2002; 37(1):89-120.

19. Palamar J. An Examination of Beliefs and Opinions about Drug Use in Relation to Personal Stigmatization towards Drug Users. J Psych Drugs 2013; 45(5):367-373. 
20. Palamar J, Kiang M, Halkitis P. Predictors of Stigmatization Towards Use of Various Illicit Drugs Among Emerging Adults. J Psych Drugs 2012; 44(3):243-251.

21. Brown S. Standardized measures for substance use stigma. Drug Alcohol Rev 2011; 116(1-3):137-141.

22. Adlaf EM, Hamilton HA, Wu F, Noh S. Adolescent stigma towards drug addiction: effects of age and drug use behaviour. Addict Behav 2009; 34(4):360-364.

23. Bastos FI, Vasconcellos MTL, De Boni RB, Bertoni $\mathrm{N}$, Coutinho CFS. III Levantamento nacional sobre o uso de drogas pela população brasileira. Rio de Janeiro: Editora ICICT/Fiocruz, 2017.

24. Laranjeira R. organizador. II Levantamento nacional de álcool e drogas (LENAD). São Paulo: Instituto Nacional de Ciência e Tecnologia para Políticas Públicas de Álcool e Outras Drogas (INPAD), Unifesp; 2014.

25. Carlini EA, organizador. II Levantamento domiciliar sobre o uso de drogas psicotrópicas no Brasil: estudo envolvendo as 108 maiores cidades do país. São Paulo: Unifesp; 2002.

26. Nutt DJ, King LA, Phillips LD. Drug harms in the UK: a multicriteria decision analysis. Lancet 2010; 376(9752):1558-1565.

27. Castaldelli-Maia JM, Martins SS, De Oliveira LG, Van Laar, De Andrade AG, Nicastri S. Use transition between illegal drugs among Brazilian university students. Soc Psychiatry Psychiatr Epidemiol 2014; 49(3):385-394.

28. Brown SA. Stigma towards marijuana users and heroin users. J Psych Drugs 2015; 47(3):213-220.

29. Thege BK, Colman I, el-Guebaly N, Hodgins DC, Patten SB, Schopflocher D, Wild TC. Social judgments of behavioral versus substance-related addictions: A population-based study. Addictive Behav 2015; 42:24-31.

30. Neff JA, Shorkey CT, Windsor LC. Contrasting faith-based and traditional substance abuse treatment programs. J Subst Abuse Treat 2006; 30(1):49-61.

31. Foster DW, Quist MC, Young CM, Bryan JL, Nguyen ML, Neighbors C. Benefit finding as a moderator of the relationship between spirituality/religiosity and drinking. Addictive Behav 2013; 38(11):2647-2652.

32. Dalgalarrondo P, Soldera MA, Corrêa Filho HR, Silva CAM. Religion and drug use by adolescents. Rev Brasil Psiquiatria 2004; 26(2):82-90.

Article submitted 19/02/2018

Approved 26/08/2019

Final version submitted 28/08/2019

Chief Editors: Romeu Gomes, Antônio Augusto Moura da Silva 
